\title{
PENGGUNAAN MULTIMEDIA INTERAKTIF DALAM PENINGKATAN MOTIVASI BELAJAR AQIDAH AKHLAK
}

\author{
Yuslinda \\ Program Studi Pendidikan Agama Islam, STAIN Pare-Pare \\ E-mail : yuslindapare@gmail.com
}

\begin{abstract}
This study aims to determine the application of interactive multimedia in increasing motivation to learn aqidah morals in MTs Pondok Pesantren Darul 'Ulum Ath-Thahiriyah Paladang. The purpose of this thesis was to obtain empirical data on character motivation to learn aqidah before taught using interactive multimedia and to obtain information on whether the application of interactive multimedia can enhance learning motivation of students in MTs Pondok Pesantren Darul 'Ulum Ath-Thahiriyah.
\end{abstract}

Keywords: Interactive Multimedia, Motivation to learn, Subjects of moral theology

\begin{abstract}
Abstrak
Penelitian ini membahas tentang penerapan multimedia interaktif dalam peningkatan motivasi belajar aqidah akhlak di Madrasah Tsanawiyah Pondok Pesantren Darul 'Ulum Ath-Thahiriyah Paladang. Adapun tujuan penelitian tesis ini adalah untuk memperoleh data empiris tentang motivasi belajar aqidah akhlak sebelum diajar menggunakan multimedia interaktif dan untuk memperoleh informasi apakah penerapan multimedia interaktif dapat meningkatkan motivasi belajar peserta didik di MTs Pondok Pesantren Darul 'Ulum Ath-Thahiriyah
\end{abstract}

Kata Kunci: Multimedia Interaktif, Motivasi belajar, mata pelajaran akidah akhlak

\section{PENDAHULUAN}

Mata pelajaran akidah akhlak merupakan salah satu mata pelajaran pendidikan agama Islam di Madrasah Tsanawiyah. Pembelajaran akidah adalah internalisasi Islam atau keyakinan pada Allah swt. yaitu bagaimana cara atau proses interaksi pembelajaran agar mempunyai keyakinan Islam atau keyakinan kepada Allah swt. yang kuat.Hal tersebut ditegaskan dalam firman Allah SWT QS.Al- Mu'minun/23: 78;

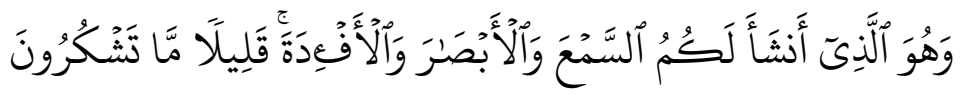

Dan Dia- lah yang telah menciptakan bagimu pendengaran, penglihatan,dan hati nurani, tetapi sedikit sekali kamu bersyukur. 
Pengamatan awal yang dilakukan di Madrasah Tsanawiyah (MTs) Pondok Pesantren Darul 'Ulum Ath- Tahiriyah Paladang menunjukkan bahwa guru yang mengajar akidah akhlak hanya menggunakan media buku paket dalam pembelajaran, mengakibatkan peserta didik tidak dapat mengembangkan potensi yang dimiliki, tidak ada semangat, merasa bosan dan tidak bisa bertahan lama di kelas saat proses pembelajaran. Hal ini menyebabkan mata pelajaran akidah akhlak kurang diminati oleh peserta didik, padahal seharusnya mata pelajaran akidah akhlak menjadi pelajaran yang dapat membuat peserta didik memiliki akidah yang kuat kepada Allah swt. dan akhlak yang mulia.

Proses pembelajaran akidah akhlak dan sarana yang dimiliki oleh sekolah belum dioptimalkan pemanfaatannya untuk menunjang pembelajar Keterbatasan-keterbatasan itu antaranya adalah guru masih sering menggunakan media yang telah tersedia yaitu textbook, selain itu metode ceramah dan dikte masih mendominasi dalam proses pembelajaran sehingga model pembelajaran cenderung teacher centered, laboratorium komputer digunakan untuk penggunaan komputer secara umum, peserta didik dilarang membawa handphone dan laptop ke sekolah,media pembelajaran akidah akhlak berbasis multimedia belum ada disekolah.

\section{KERANGKA TEORI}

\section{Multimedia Interaktif}

Kata media berasal dari bahasa latin medius yang secara harfiah berarti 'tengah', perantara atau pengantara. Dalam bahasa Arab media adalah wasilah atau pengantar pesan dari pengirim kepada penerima pesan. Berikut pendapat tentang media yang dikemukakan oleh para ahli yaitu:Gerlach dan Ely mengatakan bahwa media apabila dipahami secara garis besar adalah manusia, materi, atau kejadian yang membangun kondisi yang membuat peserta didik mampu memperoleh pengetahuan, keterampilan atau sikap.Fleming mengatkan bahwa media yang sering diganti dengan mediator yaitu penyebab atau alat yang turut campur tangan dalam dua pihak dan mendamaikannya. ${ }^{1}$

Penggunaan ketiga jenis sumber belajar ini tidak sembarangan, tetapi harus disesuaikan dengan perumusan tujuan internasional dan tentu saja dengan kompetensi guru itu sendiri. Maka guru yang pandai menggunakan media adalah guru yang bisa manipulasi media sebagai sumber belajar dan

\footnotetext{
${ }^{1}$ Azhar Arsyad, Media Pembelajaran, (Jakarta: PT Raja Grafindo Persada. 2003), h. 3
} 
sebagai penyalur informasi dari bahan yang disampaikan kepada anak didik dalam proses belajar mengajar.

Fungsi dan peran dari media pembelajaran adalah:

a. Menangkap suatu objek atau peristiwa-peristiwa tertentu

b. Memanipulasi keadaan, peristiwa, atau objek tertentu

c. Menambah gairah dan motivasi belajar peserta didik

d. Media pembelajaran memiliki nilai praktis. ${ }^{3}$

Fungsi media tersebut dapat membantu peserta didik untuk lebih memahami materi yang disampaikan oleh guru dan guru tidak harus membawa objek nyata dalam kelas karena semuanya bisa divisualisasikan.

Is multimedia a noun or an adjective? When use as a noun, multimedia refers to a technology for presenting material in a both visual and verbal forms. In this sense, multimedia means multimedia technology-devise use to present visual and verbal material. When use an adjective, multimedia can be used in the following contexts:

Multimedia learning - learning from words and pictures Multimedia message or multimedia presentation-presentations involving words and pictures. Multimedia instruction or multimedia intructional message or multimedia instructional presentation - presentations involving words and pictures that are intended to foster learning. ${ }^{4}$

(Apakah multimedia adalah kata benda atau kata sifat? Multimedia digunakan sebagai kata benda berarti multimedia mengacu pada teknologi untuk menyajikan materi dalam bentuk visual dan verbal baik. Dalam hal ini, multimedia berarti teknologi multimedia- merancang penggunaan untuk menyajikan materi visual dan verbal. Ketika menggunakan kata sifat, multimedia dapat digunakan dalam konteks berikut: presentasi multimedia yakni presentasi yang melibatkan kata-kata dan gambar instruksi multimedia atau presentasi instruksional.

Vaughan mengatakan bahwa multimedia adalah "berbagai kombinasi dari teks, grafik, suara, animasi, dan video yang disampaikan dengan menggunakan komputer atau alat elektronik lainnya". ${ }^{5}$

Rada berpendapat bahwa "multimedia merujuk ke perpaduan/sinkronisasi aliran media (any synchronized media)". Sebagai

\footnotetext{
${ }^{2}$ Syaiful Bahri Djamarah dan Aswan Zain, Strategi Belajar Mengajar, (Jakarta: PT Rineka Cipta, 2006), h. 121-124

3 Syaiful Bahri Djamarah dan Aswan Zain, Strategi Belajar Mengajar, h. 125

${ }^{4}$ Richard E Mayer, Multimedia Learning Second Edition, (Cambridge University Press: New York, 2009), h. 4-5
}

${ }^{5}$ Vaughan, Multimedia: Making it Work(2nd ed.), (USA: McGraw-Hill, 1994), h.4 
contoh dari multimedia adalah gambar bergerak yang sinkron dengan suara (termasuk siaran televisi dan film modern). ${ }^{6}$

Heinich, Molenda, Russell \& Smaldino berpendapat, "multimedia merujuk kepada berbagai kombinasi dari dua atau lebih format media yang terintegrasi kedalam bentuk informasi atau program instruksi". ${ }^{7}$

Dari segi pengertian, multimedia interaktif dapat diartikan sebagai kombinasi berbagai unsur media yang terdiri dari teks, grafis, foto, animasi video, dan suara yang disajikan secara interaktif dalam media pembelajaran. ${ }^{8}$

Berdasarkan pendapat tersebut maka dapat disimpulkan bahwa multimedia merupakan perpaduan antara berbagai media (format file) yang berupa teks, grafik, audio, dan interaksi dan digunakan untuk menyampaikan pesan/informasi dari pengirim ke penerima pesan/ informasi.

\section{Motivasi}

Motivasi memiliki akar kata dari bahasa latin movere yang berarti gerak atau dorongan untuk bergerak. Dengan begitu memberikan motivasi bisa diartikan dengan memberikan dayadorong sehingga sesuatu yang dimotivasikantersebutdapatbergerak.At kinson menjelaskan bahwa:

Motivasi dijelaskan sebagai suatu tendensi seseorang untuk berbuat yang meningkat guna menghasilkan satu hasil atau lebih pengaruh. Abraham Maslow mendefenisikan motivasia dalah sesuatu yang bersifat konstan tidak pernah berakhir, berfluktuasi dan bersifat kompleks dan hal itu merupakan karakteristik universal pada setiap kegiatan orbganisme. ${ }^{9}$

"Motivasi adalah proses yang member semangat, arah dan kegigihan perlaku". ${ }^{10}$ Motivasi adalah suatu perubahan energi di dalam peribadi seseorang yang ditandai dengan timbulnya afektif dan reaksi untuk mencapai tujuan".

Pendapat di atas, mengandung tiga unsur yang saling berkaitan, yaitu :1) motivasi dimulai dari adanya perubahan energi dalam pribadi, 2) motivasi ditandai dengan timbulnya perasaan (affective aronsal), 3)

${ }^{6}$ Green \& Brown, Multimedia Project In The Classroom, (USA: Corwin Press, Inc, 2002), h. 2

${ }^{7}$ Heinich, Molenda, Russell \& Smaldino, Instructional Media And Technologies For Learning (6th ed.), (USA: Merrill/Prentice Hall, 1999), h.229

${ }^{8}$ Didik Wira Samodra Dkk, "Multimedia Pembelajaran Reproduksi Pada Manusia", JurnalTeknologi Informasi, Volume2 Nomor 5, Oktober 2009

${ }^{9}$ Lihat Purwa Admaja Prawira, Psikologi Pendidikan Dalam Persfektif Baru, (Jogjakarta: Ar-Ruzz Media, 2011), h. 319-320.

${ }^{10}$ John W. Santrock, Psikologi Pendidikan, (Jakarta: PT Fajar Interpratama Offset, 2010), h. 510 
motivasi ditandai oleh reaksi-reaksi untuk mencapai tujuan. Motivasi menjadi suatu kekuatan, tenaga atau daya, atau suatu keadaan yang kompleks dan kesiapsediaan dalam diri individu untuk bergerak ke arah tujuan tertentu, baik disadari maupun tidak disadari.

\section{Akidah Akhlak}

Pendidikan Agama Islam di Madrasah Aliyah terdiri atas empat mata pelajaran, yaitu: Al-Qur'an hadits, Akidah akhlak, fiqh, dan tarikh (sejarah) kebudayaan Islam. Masing- masing mata pelajaran tersebut. Padadasarnya saling terkait, isi mengisi dan melengkapi. Mata pelajaran akidah akhlak di Madrasah Tsanawiyah adalah salah satu mata pelajaran PAI yang merupakan peningkatan dari akidah dan akhlak yang telah dipelajari oleh peserta didik di Madrasah ibtidaiyyah/SD. Secara substansial mata pelajaran Akidah-Akhlak di MTs memiliki kontribusi dalam memberikan motivasi kepada peserta didik untuk mempelajari dan mempraktikkan akidahnya dalam bentuk pembiasaan untuk melakukan akhlak terpuji dan menghindari akhlak tercela dalam kehidupan seharihari.

\section{METODE PENELITIAN}

Penelitian ini adalah penelitian kualitatif yang bersifat deskriptif yakni penelitian yang berusaha menyajikan data, menganalisis dan menginterpretasi untuk menuturkan pemecahan masalah yang ada sekarang berdasarkan data.

Jenis penelitian ini adalah penelitian eksperimen. Penelitian eksperimen merupakan metode inti dari model penelitian yang menggunakan pendekatan kuantitatif Peneliti meneliti di Pondok Pesantren MTs Pondok Pesantren Darul 'Ulum Ath-Thahiriyah yaitu di kelas Waktu penelitian selama 2 bulan tahun ajaran 2016/2017 Adapun populasi pada penelitian ini yaitu seluruh peserta didik di MTs Pondok Pesantren Darul 'Ulum Ath-Thahiriyah. Peneliti telah menentukan sampel pada penelitian ini yaitu kelas VIII MTs Pondok Pesantren Darul 'Ulum Ath-Thahiriyah.

Metode yang digunakan untuk memperoleh data lapangan, yaitu sebagai berikut:

a. Observasi adalah mengamati secara langsung proses pembelajaran yang dilakukan guru akidah akhlak dan peserta didik di kelas.

b. Tes motivasi adalah cara untuk mengumpulkan data mengenai media pembelajaran interaktif yang berbentuk pengajuan pernyataan tertulis tentang motivasi 
c. Teknik analisis yang digunakan peneliti yaitu statistik t-test dengan rumus:

$$
t=\frac{\bar{X}_{1}-\bar{X}_{2}}{\sqrt{\frac{\left(n_{1}-1\right) S_{1}^{2}+\left(n_{2}-1\right) S_{2}^{2}}{n_{1}+n_{2}-2}\left(\frac{1}{n_{1}}+\frac{1}{n_{2}}\right)}}
$$

$\mathrm{r}=$ nilai korelasi $\mathrm{x}_{1}$ dengan $\mathrm{x}_{2}$

$\mathrm{n} \quad=$ jumlah sampel

$\mathrm{x}_{1} \quad=$ rata - rata sampel ke 1

$\mathrm{x}_{2} \quad=$ rata - rata sampel ke 2

$\overline{\mathrm{s}_{1}} \quad=$ standar deviasi sampel ke 1

$\mathrm{s}_{2} \quad=$ standar deviasi sampel ke 2

$\mathrm{S}_{1} \quad=$ varians sampel ke 1

$\mathrm{S}_{2} \quad=$ varians sampel ke $2 .^{11}$

\section{HASIL PENELITIAN DAN PEMBAHASAN}

\section{Hasil Analisis Deskriptif Setelah Diberi Perlakuan}

Analisis deskriptif persentase digunakan untuk mengetahui motivasi peserta didik yang diberikan perlakuan. Perlakuan yang diberikan berupa penggunaan media pembelajaran akidah akhlak berbasis multimedia pembelajaran. Penelitian ini menggunakan skala psikologi dengan skor tertinggi 5 dan terendah 1 dengan jumlah item 21 dan jumlah responden sebanyak 27 orang serta jumlah skor total setiap item adalah 135, jumlah skor total keseluruhan adalah 2.835

\section{Motivasi Belajar Peserta Didik Sebelum Diajar Menggunakan Multimedia Interaktif}

Berdasarkan observasi awal dan analisis data yang telah dilakukan, maka motivasi belajar peserta didik sebelum diajar menggunakan multimedia interaktif yaitu:

a. Motivasi Intrinsik

1) Antusias Tinggi

Antusias tinggi merupakan ciri- ciri dari peserta didik yang memiliki motivasi mengikuti proses pembelajaran akidah akhlak. Peserta didik yang memiliki motivasi mengikuti proses pembelajaran akidah akhlak seharusnya ditunjukkan dengan keyakinan yang kuat dari peserta didik untuk mendapat nilai yang tinggi pada proses pembelajaran akidah akhlak. Namun saat pre test diperoleh hasil yang belum signifikan dari ciri-ciri tersebut dan diperoleh hasil tinggi.

11 Riduwan Dan Sunarto, Pengantar Statistika Untuk Penelitian Pendidikan, Sosial, Ekonomi, Komunikasi, Dan Bisnis, (Bandung: Alfabeta, 2015), h. 12 
2) Mengendalikan perhatian dan energinya pada proses pembelajaran Pengendalian perhatian dan energi merupakan ciri-ciri peserta didik yang memiliki motivasi mengikuti proses pembelajaran akidah akhlak. Peserta didik yang memiliki motivasi mengikuti proses pembelajaran akidah akhlak seharusnya ditunjukkan dengan perhatian yang tinggi pada proses pembelajaran, tidak jalan-jalan di kelas saat guru menjelaskan materi beriman kepada rasul Allah SWT dan tidak membuat keributan dikelas saat guru menjelaskan materi beriman kepada rasul Allah SWT. Namun saat pre test diperoleh hasil yang berbeda dari ciri-ciri tersebut dan diperoleh hasil tinggi.

3) Tekun menghadapi tugas dalam proses pembelajaran

Tekun mengerjakan tugas merupakan ciri-ciri peserta didik yang memiliki motivasi belajar yang tinggi. Motivasi peserta didik mengikuti proses pembelajaran akidah akhlak seharusnya ditunjukkan dengan kemudahan peserta didik dalam mengerjakan tugas. Namun saat pretest diperoleh hasil yang berbeda dari ciri- ciri tersebut dan diperoleh hasil tinggi.

4) Senang dan rajin belajar, penuh semangat, cepat bosan dengan tugastugas rutin, dapat mempertahankan pendapat.

Senang dan rajin belajar, penuh semangat, cepat bosan dengan tugastugas rutin, dapat mempertahankan pendapat merupakan ciri-ciri peserta didik yang memiliki motivasi belajar yang tinggi. Peserta didik yang memiliki motivasi belajar yang tinggi pada mata pelajaran akidah akhlak seharusnya ditunjukkan dengan semangat dengan jumlah pengulangan materi pembelajaran beriamn kepada rasul Allah SWT, tidak melamun ketika guru menampilkan materi beriman kepada rasul llah SWT, dan tidak tidur dikelas saat guru menampilkan materi ajar. Namun saat pre test diperoleh hasil yang berbeda dari ciri-ciri tersebut dan diperoleh hasil tinggi. Hal ini menunjukkan bahwa peserta didik masih kurang semangat dalam mengikuti proses pembelajaran.

b. Motivasi Ekstrinsik

1) Tertarik pada media pembelajaran akidah akhlak berbasis multimedia artinya tidak acuh tak acuh.

Dari hasil pre test diperoleh diperoleh bahwa peserta didik kurang termotivasi dan dalam kategori tinggi. Dari hasil tersebut menunjukkan bahwa masih perlu peningkatan kesadaran peserta didik dalam mengambil manfaat pada cerita yang ada dalam materi beriman kepada rasul Allah SWT, tidak tertarik dengan halamanhalaman materi beriman kepada rasul Allah SWT, kurang semangat 
membaca materi akidah akhlak karena gaya tulisan kurang menarik, sebagaian besar isi materi kurang dipahami sehingga motivasi untuk tahu materi selanjutnya jadi berkurang, dan materi yang diberikan kurang lengkap sehingga masih mencari refrensi selain dari media yang ditampilkan guru.

2) Tertarik pada mata pelajaran yang diajarkan

Pada pre test yang dilakukan oleh peneliti menunjukkan hasil yang sedang terhadap materi yang disajikan guru pada proses pembelajaran. Pada pre test menunjukkan bahwa peserta didik masih perlu termotivasi mengikuti pelajaran akidah akhlak, masih belum dapat mengambil pada mata pelajaran yang diajarkan dan keinginan kurang dalam mengikuti mata pelajaran akidah akhlak.

3) Variasi aktivitas belajar lebih banyak

Hasil pre test menunjukkan bahwa peserta didik masih kurang memiliki motivasi, karena cara guru masih perlu peningkatan dalam hal interaktif mengajar, materi ajar yang disampaikan sangat monoton dan masih perlu adanaya variasi pembelajan, guru layaknya seperti penceramah dan masih kurang komunikatif.

\section{Penerapan Multimedia Interaktif dapat Meningkatkan Motivasi Belajar Peserta Didik}

Pada penelitian ini media memiliki peranan sangat penting guna meningkatkan motivasi belajar peserta didik dalam proses pembelajaran akidah akhlak. Selama pemberian perlakuan, peneliti menyajikan materi ajar beriman kepada rasul Allah menggunakan power point dan dilengkapi dengan teks gambar, video, audio, quis dan latihan. untuk memperdalam maksud dan tujuan pembelajaran maka digunakan pula variasi model pembelajaran yang sesuai dengan media yang sudah disediakan.

\section{PENUTUP}

Berdasarkan hasil penelitian di kelas VIII MTs Pondok PesantrenAth- Thahiriyah Paladang, maka dapat disimpulkan bahwa:

1. Motivasi peserta didik dalam proses pembelajaran akidah akhlak sebelum diberi perlakuan dengan penerapan multimedia interaktif berdasarkan kriteria interpretasi tergolong dalam kategori tinggi yaitu $71,11 \%$. Hal tersebut berarti bahwa media konvensional dengan menggunakan textbook pada proses pembelajaran masih efektif digunakan di Madrasah Tsanawiyah Pondok Pesantren Darul 'ulumath-Thahiriyyah Paladang.

2. Motivasi peserta didik mengikuti proses pembelajaran akidah akhlak sesudah diberi perlakuan berupa penerapan multimedia interaktif meningkat. Hal tersebut dapat diketahui dari hasil uji t-test 
yang menunjukkan $t$ hitung $(6,621) \mathrm{t}$ tabel $(2,05553)$ dan hasil analisis tiap-tiap indikator yakni 89,99\%. Oleh karena itu, penerapan multimedia interaktif efektif untuk meningkatkan motivasi belajar peserta didik mengikuti proses pembelajaran akidah akhlak. Dengan demikian, hipotesis yang diajukan diterima

\section{DAFTAR PUSTAKA}

Daradjat, Zakiah. Kepribadian Guru. Jakarta: Bulan Bintang, 2005.

Admaja, Purwa Prawira. Psikologi Pendidikan Dalam Persfektif Baru. Jogjakarta: Ar-Ruzz Media. 2011.

Arsyad, Azhar. Media Pembelajaran. Jakarta: PT Raja Grafindo Persada. 2003.

Arsyad. Media Pembelajaran. Jakarta: PT Raja Grafindo Persada. 2010.

Badudu. Inilah Bahasa Indonesia Yang Benar. Jakarta: PT Gramedia Pustaka Utama. 1996

Dimyati, Mudjiono. Belajar dan Pembelajaran.Jakarta: PT Rineka Cipta: 1999.

Furqan, Arief. Pengantar Penelitian DalamPendidikan. Yogyaakarta: Pustaka Pelajar. 2011.

Gay, Geoffrey, Mills, Peter Airasian. Educational Research Competencies For Analysis And Applications. Pearson Education: America. 2012.

Green \& Brown. Multimedia Project In The Classroom. USA: Corwin Press, Inc, 2002.

Heinich, Molenda, Russell \& Smaldino.Instructional Media And Technologies For Learning (6th ed.). USA: Merrill/Prentice Hall. 1999.

Mayer, Richard E. Multimedia Learning Second Edition. Cambridge University Press: New York. 2009.

Muhamad, Ali. Pengembangan Media Pembelajaran Interaktif Pada Mata Kuliah Medan Elektromagnetik. Jurnal Edukasi. Yogyakarta: Vol. 5, No. 1/Maret 2009.

Padmanthara. Pembelajaran Berbantuan Komputer Dan Manfaat Sebagai Media Pembelajaran. dalam Jurnal TEKNODIK. Vol. 22. Pp, 2007. h. 130144.

Rahman, Abdul Saleh, Muhbib Abdul Wahab. Psikologi Suatu Pengantar Dalam Perfektif

Islam. Jakarta:Kencana. 2004. Riduwan dkk. Pengantar statistika

untuk penelitian pendidikan, sosial, ekonomi, komunikasi, dan bisnis. Bandung: alfabeta. 2015

Santrock, John W. Psikologi Pendidikan. Jakarta: PT Fajar Interpratama Offset. 2010. 
138 | Yuslinda/ IQRO: Journal of Islamic Education Vol. 1, No.2, Desember 2018. 129-138

Halaman ini sengaja dikosongkan 